\title{
ИСТОРИЯ
}

DOI: $10.17805 /$ trudy.2015.3.7

\section{ТЕТРАЛОГИЯ О СЛАВЯНСКОМ МИРЕ}

\author{
Г. А. Елисеев \\ (Историко-просветительское общество «Радетель», г. Москва)
}

Аннотация: $\quad$ с статье представлена рецензия на цикл работ С.В.Алексеева, посвященных истории славян в V-VIII вв.

Ключевые слова: история славян, раннее средневековье, историография, Сергей Викторович Алексеев.

\section{A TETRALOGY ON THE SLAVIC WORLD}

\author{
G. A. Eliseyev \\ (Radetel' Historical and Educational Society, Moscow)
}

\begin{abstract}
This is a review of a series of works by S.V. Alekseev on the history of the Slavs in the 5th-8th centuries CE.

Keywords: Slavic history, early Middle Ages, historiography, Sergey Viktorovich Alekseyev
\end{abstract}

Недостаток подлинных обобщающих работ - заметный недостаток отечественной медиевистики последних десятилетий. С одной стороны, это тормозит развитие научного знания, не давая ему подниматься на более высокий уровень осмысления информации источников. С другой - мешает коммуникации между специалистами из разных областей исторического знания, а также затрудняет знакомство с достижениями исторической науки широкого круга заинтересованных гуманитариев.

Ввиду этого отрадно появление в печати книг, в которых высокий научный уровень успешно сочетается с широтой охвата проблемы. Обобщающая монография по ранней истории «Славянская Европа», ранее выходившая в свет отдельными изданиями в двух томах и однотомником (Алексеев, 2007, 2008, 2009), теперь автором решительным образом переработана, дополнена и улучшена и превратилась в целую тетралогию о славянском мире.

Создатель этого подробного и скрупулезного исследования - профессор, доктор исторических наук Сергей Викторович Алексеев - изве- 
стен не только своими сугубо профессиональными изысканиями, но и подробными биографиями древнерусских князей Владимира Святого и Ярослава Мудрого, предназначенными как для специалистов, так и для самого широкого круга читателей.

Первый том его тетралогии - «Заря славянства» (Алексеев, 2015а) посвящен периоду с V по первую половину VI века н. э. и разбит на следующие разделы: «Словене и анты», «Первый штурм имперских границ», «Славянский север». Второй том - «Славяне и авары» (Алексеев, 2015b) - рассказывает о событиях второй половины шестого - начала VII века н. э. В него вошли разделы «Приход авар», «Славяне после прихода авар», «Второй штурм имперских границ», «Битва за Дунай». Третий том - «Великое расселение славян» (Алексеев, 2015с) - посвящен событиям, ограниченным хронологическими рамками 602-679 гг. (разделы «Завоевание Балкан», «Эпоха Само», «В новых пределах»). И, наконец, четвертый том - «Славяне на пороге цивилизации» (Алексеев, 2015d) - повествует о славянской истории с 679 по 800 гг. н. э. В него автором были включены разделы «Болгария, Македония, Эллада», «Хорутания, Хорватия, Сербия», «Славяне западные и восточные. Конец VII - вторая треть VIII в.», «Славяне западные и восточные. Последняя треть VIII в.».

По охвату материала и по подробному изложению исторических событий книги С. В. Алексеева не только могут быть сравнимы с известной «Степной трилогией» Л. Н. Гумилева, но кое в чем ее и превосходят. Во всяком случае, автор тетралогии о славянской Европе не позволяет себе излишне фантазировать или выдвигать непроверенные гипотезы. Нет у него и желания подгрести все излагаемые исторические факты под собственную, всеобъемлющую историософскую теорию. С. В. Алексеев в своих трудах остается на жесткой почве исторических фактов, в то же время в необходимых случаях вполне четко пописывая и принципиально обосновывая собственные исторические воззрения и концепции.

Заметное достоинство этих четырех книг заключается в том, что любой их читатель получает компендиум проверенных научных сведений об истории славянства в Центральной и Восточной Европе с V по VIII век включительно. Это своего рода фиксация самых разных аспектов изучения славянского мира том виде, в каком оно существует сейчас - в начале XXI века. И от этого тетралогия С. В. Алексеева воспринимается как глоток свежего воздуха среди засилья всякого рода псевдоисторических трактатов о древних славянах, построивших якобы все памятники древности, начиная с пирамид, и заодно «выкопавших Черное море».

Автор подробно вводит в текст археологическую информацию, но делает это настолько удачно, что обычно вызывающие скуку сведения об вариациях керамики или специфике погребений действительно подчеркивают особенности тех или иных локальных славянских культур. Пись- 
менная история, в которой о славянах повествуют их соседи, в тексте С. В. Алексеева сочетается с безмолвными свидетельствами из археологических раскопов, в комплексе создавая целостную картину славянской жизни на протяжении веков.

И любопытно, что реальная история славянства, точно соответствующая письменным источникам из сопредельных стран и археологическим изысканиям, оказывается куда более интересной, нежели любые вымыслы о «гиперборейских праславянах, прилетевших с Венеры или Марса».

История славянского мира полна как живых, невероятно занимательных перипетий, так и сложнейших научных проблем. Следует заметить, что С. В. Алексеев на протяжении своего труда явно осознавал, что создает текст и абсолютно научный, и одновременно - широко доступный. Поэтому обсуждение дискуссионных проблем он широко и обильно выносил в примечания. Те, кому это интересно, или те, кто глубоко погружен в тему (специалисты), с удовольствием эти примечания изучат. А те, кому важна только сконцентрированная и научно обоснованная информация, - спокойно продолжат читать текст, не отвлекаясь на споры о научно значимых, но малопонятных обычному читателю частностях. Поэтому даже подробный рассказ об историографической дискуссии по пресловутому «норманнскому вопросу» справедливо отнесен автором в примечания (Алексеев, 2015d: 339-345).

Эти книги С. В. Алексеева каждый педагог высшей школы может смело рекомендовать своим ученикам, если они ему задают сакраментальный вопрос: «А что можно почитать действительно научное, но нормально написанное по истории славян?» (Множество раз лично сталкивался и с этим вопросом, и с благодарностью от тех, кто прочитал «Славянскую Европу»).

Однако, у автора тетралогии в будущем еще есть огромное поле для применения сил.

Во-первых, в литературе самым «загаженным» и «замусоренным», переполненным мистификациями и домыслами, оказывается описание не столько периода, которому посвящены четыре книги С. В. Алексеева, сколько более раннее время - эпоха, когда только формировались даже не славянские, а праславянские общности. Вот здесь доморощенные мифотворцы, начиная с анонимного создателя «Влесовой книги», разгулялись не на шутку. И книга, которая подобно «Славянской Европе», подвела бы итог научному изучению этногенеза славян и разоблачению мифов о всевозможных арктических или памирских прародинах, оказалась бы очень и очень востребованной. С. В. Алексееву, тонкому и внимательному исследователю, стоило бы подумать о подобном труде. Ведь и сам он четко указывает в «Заре славянства»: «Однако история праславян началась, как мы видели, с гораздо более раннего времени. Если и можно полагать V 
столетие началом собственно славянской истории, то лишь условно. Прошлое славян насчитывало к тому времени не одно тысячелетие» (Алексеев, 2015а: 51). Путь к такому исследованию намечает серия статей автора, посвященных проблемам происхождения славян и реконструкции праславянской культуры (Алексеев, 2011, 2013а и др.).

Во-вторых, просто напрашивается продолжение тетралогии, посвященное еще более судьбоносным временам в истории славянства. Тем, про которые сам автор четко выразился в финале четвертого тома «Славяне на пороге цивилизации»: «Внешние угрозы и влияния подталкивали славян - но не являлись единственной побудительной причиной. Становление славянских государств, зарождение славянской цивилизации являлось внутренней потребностью славянского общества. И именно внутренними силами, на веками выстраивавшемся фундаменте, появились в IX-XI столетиях средневековые государства Славянского Мира» (Алексеев, 2015d: 287). И не стоит С. В. Алексееву отказываться от подобного труда, ссылаясь на уже написанные им биографии великих князей. Хотя бы потому, что личная биография - это совсем не то, что подробная картина жизни и судьбы целого государства. И, в любом случае, необходим рассказ обо всех славянских государствах этой эпохи, а не только об одной лишь Киевской Руси. Здесь у автора тоже есть хороший научный задел - источниковедческие исследования, посвященные нерешенным вопросам раннесредневековой истории южных славян (Алексеев, 2013b, 2014 и др.).

Очевидно, что речь идет о значительной работе, которая может вылиться в обширный, гораздо более объемный в сравнении с имеющимся монографический цикл. В то же время результатом такой без преувеличения огромной работы может стать целостное и последовательное представление оригинальной и представляющей большой научный интерес авторской концепции средневековой истории славянства.

\section{СПИСОК ЛИТЕРАТУРЫ}

Алексеев, С. В. (2007) Славянская Европа VII-VIII вв. М. : Вече.

Алексеев, С. В. (2008) Славянская Европа V-VI вв. М. : Вече.

Алексеев, С. В. (2009) Славянская Европа V-VIII вв. М. : Вече.

Алексеев, С. В. (2011) К реконструкции праславянской мифологии // Знание. Понимание. Умение. № 4. С. 79-89.

Алексеев, С. В. (2013a) Реконструкция праславянской обрядности: календарные обычаи // Научные труды Московского гуманитарного университета. № 3. С. 21-41.

Алексеев, С. В. (2013b) Структура легендарной части «Летописи попа Дуклянина» // Научные труды Московского гуманитарного университета. 
№ 8. C. $4-13$.

Алексеев, С. В. (2014) Святой Иван-Владимир Зетский в «Летописи попа Дуклянина» и других источниках // Научные труды Московского гуманитарного университета. № 6. С. 4-17.

Алексеев, С. В. (2015а) Заря славянства. V - первая половина VI в. М.: Вече.

Алексеев, С. В. (2015b) Славяне и авары. Вторая половина VI в. М. : Вече.

Алексеев, С. В. (2015с) Великое расселение славян. М. : Вече.

Алексеев, С. В. (2015d) Славяне на пороге цивилизации. 679-800 гг. М.: Вече.

Елисеев Глеб Анатольевич - кандидат исторических наук, доцент, руководитель исследовательской группы Историко-просветительского общества «Радетель». Адрес: 111395, Россия, г. Москва, ул. Юности, д. 5, корп. 3. Тел.: +7 (499) 374-55-81. Эл. адрес: geliseev@mail.ru

Eliseyev Gleb Anatolyevich, Candidate of History, Associated Professor, Head of Research Group, Radetel' Historical and Educational Society. Postal address: 5 Yunosti St., 111395 Moscow, Russian Federation. Tel.: +7 (499) 37455-81.E-mail: geliseev@mail.ru 